\title{
DESIGNING THE CUSTOMER (INSURERS) SATISFACTION MODEL OF THE IRANIAN INSURANCE INDUSTRY EMPHASIZING IRANIAN-ISLAMIC CHARACTERISTICS
}

\author{
M. H. Hosseini ${ }^{1}$, L. F. Dehkordi ${ }^{2}$, M. M. Parhizgar ${ }^{3}$, H. Moezzi $^{*}, 4$ \\ ${ }^{1}$ Professor in Payam-e Noor University, Tehran, Iran \\ ${ }^{2}$ Associate Professor in Tarbiat Modarres University, Tehran, Iran \\ ${ }^{3}$ Associate Professor in Payam-e Noor University, Tehran, Iran \\ ${ }^{4}$ Ph.d Student in Business Management, Payam-e Noor University, Tehran, Iran
}

Published online: 08 August 2017

\begin{abstract}
The present study aim was to designing a model to create satisfaction for insurers in the insurance industry of Iran (according to Iranian-Islamic characteristics). It should be noted that according to the methodology presented for this research, the approach of this research has been qualitative. The qualitative modeling process of this research, which was carried out in the grounded theory method, formed the conceptual model of research. The statistical population consisted of a group of experts. Also, in this research, a deep and unstructured interviewing tool was used to data collection. Finally, the results of the research led to the presentation of a model of satisfaction process for insurers in the insurance industry of Iran (according to Iranian- Islamic characteristics). In terms of purpose, this research is applied, in terms of method is qualitative and in terms of approach is survey-exploration.
\end{abstract}

Keywords: Customer Satisfaction, Insurance Industry, Grounded Theory (GT)

Author Correspondence, e-mail: dr.moezzihamed@gmail.com doi: http://dx.doi.org/10.4314/jfas.v9i2s.843 


\section{Introduction and statement of the problem}

Since customers play an essential role in the process of organizational activities and affect their organization's fate through thoughts and policies, so, not only recognizing their obvious needs, but also predicting, determining and managing the hidden needs of customers, designing and implementing programs, and providing services to address these needs are key and organizational pillars. Several studies have shown that the cost of obtaining a new customer is 5 times higher than the existing customer and it has also been mentioned that a one percent reduction in customer satisfaction would reduce the company's return by 5\% (Tsu-Wei and Lu-Ming, 2016). Customer satisfaction is one of the most important consequences for a variety of business organizations (including companies active in the insurance industry), which has been approved by the customer philosophy and the main concepts of continuous improvement. For this reason, customer satisfaction must be measured and converted into a number of measurable parameters. Customer satisfaction measurement can be used as the most reliable feedback system, because it provides an effective, direct, significant and realistic way of meeting customer expectations and priorities. Accordingly, customer satisfaction provides a standard of performance and a possible standard of excellence for any business organization. Also, customer satisfaction measurement creates a sense of success and reaches the goal for all involved employees in the process of serving customers; so, satisfaction measurement will lead people to higher levels of productivity. Customer satisfaction should be converted into a number of measurable parameters that understood and affected by people (Chen-Ying Lee et al., 2015)

Since insurance companies are also a for-profit organization, they must pay special attention to their customers (ie insurers). Because neglecting customer satisfaction, which is the result of neglecting his wants and needs, is a failure of these companies. Regardless of the importance of this issue in the Iranian insurance industry, unfortunately, the lack of a comprehensive native model for assessing customer satisfaction in this annoying service area is still absent. This has led to various insurance companies in the country, in order to measure the satisfaction of its customers of types and a variety of non-native models that are sometimes designed specifically for a particular country's service market. Such non-native models, almost all of which lack the cultural and religious dimensions, will make insurance companies unable to see a clear view of their customers' satisfaction and, of course, decisions based on these types of findings also have less efficiency and effectiveness. For this reason, in the insurance industry of the country, 
designing a comprehensive native model for evaluating customer satisfaction, in addition to the technical dimensions, also include cultural and Islamic dimensions of the insurance industry, and it is clearly understood. Therefore, the present study sought to eliminate this theoretical vacuum in the insurance industry of Iran and tried to investigate different models of customer satisfaction in different service industries, and, using the experts' opinions of this industry in Iran; it will design an Iranian-Islamic model of customer satisfaction with the insurance industry.

\section{Research background}

Tsu-Wei Yu \& Lu-Ming Tseng (2016) conducted a research entitled "The role of vendors in developing loyalty of life insurance customers." The results of this research showed that there is a relationship between characteristics and personality of vendors and sales behaviors can affect the life insurance customers' loyalty strongly and positivly.

Chen-Ying Lee et al (2015) conducted a research entitled "The relationship between attitude attitude and customer satisfaction with mobile application services: an empirical study in the life insurance industry". This research was conducted on 538 insurers in Taiwan. The research results showed that the provision of applied services through mobile systems in the life insurance field could lead to a positive attitude and satisfaction of the customers of this industry.

Lee (2012) has been shown that customer attitudes toward innovation in services (new services) can affect their future purchasing intention. Also, in this research, it was determined that the following variables affect the attitude of customers towards new services: the ease and perceived convenience in using the service, perceived price justice pertaining to service, satisfaction with service availability, fashion service, and service risk aversion. Wang and $\mathrm{Wu}$ (2012) concluded that the perception and attitude of the customers towards the company could affect the loyalty of customers and the establishment of a long-term relationship between them and the company.

Estiri, Hosseini and Yazdani (2011) conducted a research entitled "criteria for customer satisfaction in Islamic banking: a case study of Iranian banks " and aimed at developing a customer satisfaction scale in the Islamic banking sector in Iran. They concluded in the end that the quality of services in the banking industry of Iran, in accordance with the Islamic trade has a two-factor structure: the quality of the proposition of value and quality of delivery and service delivery. 
Singh and Kaur (2011), in a research entitled "customer satisfaction and World Bank: an empirical study", and with the goal of determining the factors affecting customer satisfaction that was performed in India, they concluded that customer satisfaction in global banks was affected by the following factors: employee responsibility, physical and tangible appearances, social responsibility, service innovation, competence, and reliability. Upadhyaya \& Badlani (2011), by conducting a research on life insurance companies in India, concluded that the role of technology in improving quality and as a result of satisfying customers, it is very important.

In another study, Sheng \& Liu (2010) showed that the quality of online services (including in banks) could have a significant impact on customer satisfaction and loyalty.

Ganguli and Roy (2010) conducted a research entitled "The general dimensions of quality of technology-based services in the banking industry", aimed at identifying the general dimensions of service quality in technology-based banking and assessing the impact of these dimensions on customer satisfaction and loyalty. In the end, they identified four general dimensions of customer service, technology security and information quality, convenience and ease of technology, and the ease and credibility of technology use and concluded that the dimensions of customer service and the ease and credibility of technology have a positive and significant effect on customer satisfaction and loyalty. In a study conducted by the New Zealand Communications Industry, Danaher and Gallagher (1997) found that the quality of services offered in the service industries, including communication industries has a great effect on customer satisfaction. The results of this study indicate the need for more extensive research to document the demands of customers and their expectations of communication services. Based on which it is possible to develop the necessary programs to improve the quality of services in accordance with the needs and demands of the customer. Previous research and models used in them showed that, in all of the studied models 19 major variables were considered and evaluated. Table (1) shows these 19 variables and relationship of each with different models: 
Table 1. Tabulation of results of previous studies (existing models of customer satisfaction measurement)

\begin{tabular}{|c|c|c|c|c|c|c|c|c|c|c|c|c|}
\hline$\stackrel{0}{Z}$ & Model & 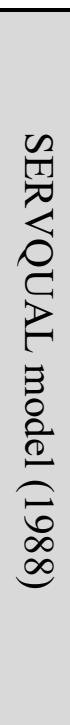 & 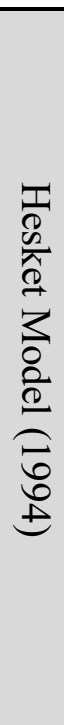 & 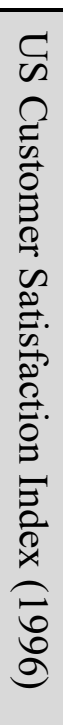 & 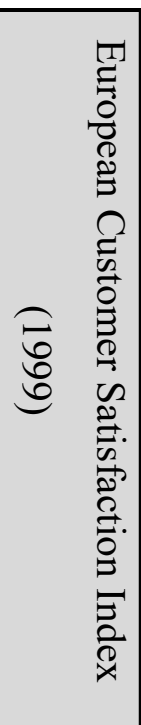 & 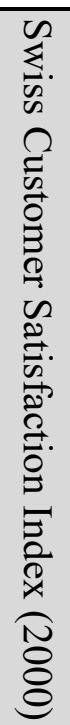 & $\begin{array}{l}\overline{0} \\
0 \\
0 \\
0 \\
0 \\
0 \\
0 \\
0 \\
0 \\
0 \\
0 \\
0 \\
0 \\
0 \\
0\end{array}$ & 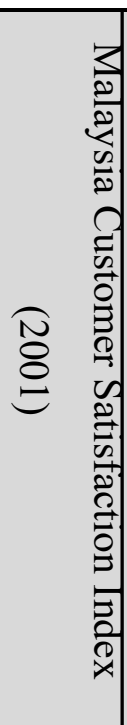 & 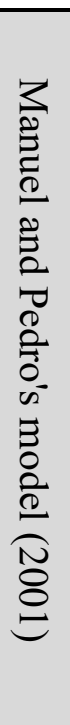 & 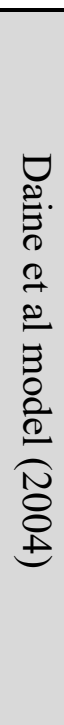 & 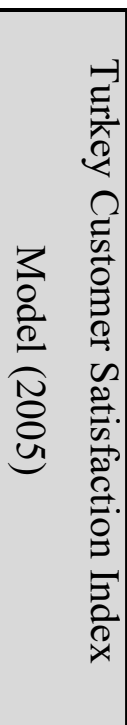 & 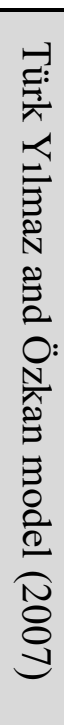 \\
\hline 1 & Expectations & & & $*$ & $*$ & & & $*$ & $*$ & $*$ & $*$ & $*$ \\
\hline 2 & Perceived quality & & & $*$ & $*$ & & & $*$ & $*$ & $*$ & $*$ & $*$ \\
\hline 3 & Perceived value & & $*$ & $*$ & $*$ & & $*$ & $*$ & $*$ & $*$ & $*$ & $*$ \\
\hline 4 & $\begin{array}{c}\text { Customer } \\
\text { satisfaction }\end{array}$ & & $*$ & $*$ & $*$ & $*$ & $*$ & * & $*$ & $*$ & $*$ & $*$ \\
\hline 5 & $\begin{array}{l}\text { Customer } \\
\text { complaint }\end{array}$ & & & $*$ & & & & & & $*$ & & \\
\hline 6 & Image & & & & $*$ & & & $*$ & $*$ & $*$ & $*$ & $*$ \\
\hline 7 & Client conversation & & & & & $*$ & & & & & & \\
\hline 8 & $\begin{array}{c}\text { Employee } \\
\text { perceived } \\
\text { commitment }\end{array}$ & & & & & & & & $*$ & & & \\
\hline 9 & $\begin{array}{c}\text { Perceived staff } \\
\text { satisfaction }\end{array}$ & & * & & & & $*$ & & $*$ & & & \\
\hline 10 & $\begin{array}{c}\text { Employee } \\
\text { perceived loyalty }\end{array}$ & & * & & & & $*$ & & $*$ & & & \\
\hline 11 & maintain staff & & $*$ & & & & & & & & & \\
\hline 12 & Employee & & $*$ & & & & & & & & & \\
\hline
\end{tabular}




\begin{tabular}{|c|c|l|l|l|l|l|l|l|l|l|l|l|}
\hline & productivity & & & & & & & & & & & \\
\hline 13 & Communications & & & & & & & & & $*$ & & \\
\hline 14 & $\begin{array}{c}\text { Trust and } \\
\text { confidence }\end{array}$ & $*$ & & & & & & & & $*$ & $*$ & \\
\hline 15 & $\begin{array}{c}\text { Control and } \\
\text { management of } \\
\text { complaints }\end{array}$ & & & & & & & & & & $*$ & \\
\hline 16 & Change fee & & & & & & & & & & $*$ & \\
\hline 17 & $\begin{array}{c}\text { Physical condition } \\
\text { and tangibility }\end{array}$ & $*$ & & & & & & & & & & \\
\hline 18 & Answering & $*$ & & & & & & & & & & \\
\hline 19 & Sympathy & $*$ & & & & & & & & & & \\
\hline
\end{tabular}

\section{METHODOLOGY}

\subsection{Statistical population of the research:}

The statistical population of this research was a group of university experts and executives of Iran's insurance industry. In this research, the researcher achieved theoretical saturation after completing 13 interviews.

\subsection{Data collection tool:}

In this research, collection data tool was deep and open interviewing with experts.

\subsection{Data Analysis:}

In this research, triangular coding of the grounded method (open coding, axial coding, and selective coding) and the paradigm model were used to analyze the data and achieve the conceptual model of the research.

\section{The Grounded Theory method}

\subsection{Open coding}

This phase of analysis was dedicated to identifying and extracting basic concepts from interviews. Accordingly, after conducting each interview, the investigator extracted the concepts contained in the interview with a multiple review. A total of 13 interviews were conducted, 93 primary concepts were extracted and classified as 36 clusters. 


\subsection{Axial coding}

At this stage, more general categories should be created through the classification of conceptual clusters formed in the previous step. To do this, we tried to integrate clusters of the same subcategory into a more general category by carefully reviewing the clusters and concepts included therein. After this process, the 36 clusters obtained in the previous stage were classified into 11 categories. Then, with the supervision of the respected professor, it was tried to name these categories appropriately. The result of this step is shown in Table (2):

Table 2. Classification of clusters in terms of categories and naming the categories

\begin{tabular}{|c|c|}
\hline Categories & Clusters \\
\hline \multirow{3}{*}{ Innate needs } & The need for financial security \\
\hline & The need for psychological security \\
\hline & $\begin{array}{l}\text { The need to have a backing and heart } \\
\text { strength }\end{array}$ \\
\hline \multirow{3}{*}{$\begin{array}{l}\text { Cultural- } \\
\text { religious } \\
\text { contexts }\end{array}$} & The need for believer prospects \\
\hline & $\begin{array}{l}\text { The insurer's belief in divorce and } \\
\text { divorce }\end{array}$ \\
\hline & $\begin{array}{c}\text { The believer is not biting from a hole } \\
\text { twice. }\end{array}$ \\
\hline \multirow{5}{*}{$\begin{array}{l}\text { Provisions of } \\
\text { Islamic Sharia }\end{array}$} & Trust and honesty of the insurer \\
\hline & $\begin{array}{l}\text { Appropriate treatment of the insurer with } \\
\text { the insurer }\end{array}$ \\
\hline & $\begin{array}{c}\text { Compensation of the insurer for a low } \\
\text { profit }\end{array}$ \\
\hline & $\begin{array}{l}\text { The possibility of termination of the } \\
\text { insurance contract by the insurer }\end{array}$ \\
\hline & Do not differentiate between customers \\
\hline \multirow{2}{*}{$\begin{array}{c}\text { Acquiring } \\
\text { internal } \\
\text { consistency of } \\
\text { insurance and }\end{array}$} & $\begin{array}{l}\text { Satisfaction of the needs and wishes of } \\
\text { the insurer }\end{array}$ \\
\hline & $\begin{array}{l}\text { The insurer's intention to receive future } \\
\text { insurance services (from an insurance }\end{array}$ \\
\hline
\end{tabular}




\begin{tabular}{|c|c|}
\hline \multirow{2}{*}{$\begin{array}{l}\text { establishing } \\
\text { loyalty in him }\end{array}$} & company) \\
\hline & $\begin{array}{l}\text { Introduction of insurer to friends and } \\
\text { acquaintances }\end{array}$ \\
\hline \multirow{4}{*}{$\begin{array}{l}\text { Obvious and } \\
\text { hidden needs } \\
\text { of insurers }\end{array}$} & $\begin{array}{l}\text { The insurer's belief in the usefulness of } \\
\text { the insurance }\end{array}$ \\
\hline & $\begin{array}{l}\text { The insurer's belief in the necessity of } \\
\text { insurance }\end{array}$ \\
\hline & $\begin{array}{l}\text { The insurer's awareness of its } \\
\text { expectations from the insurer }\end{array}$ \\
\hline & The hidden needs of the insurer \\
\hline \multirow{2}{*}{$\begin{array}{c}\text { Islamic } \\
\text { worldview }\end{array}$} & Preceding God's will on all matters \\
\hline & God's observance of all acts of mankind \\
\hline \multirow{3}{*}{$\begin{array}{l}\text { Religious } \\
\text { beliefs }\end{array}$} & Blessed charity \\
\hline & You will get the same from every hand \\
\hline & $\begin{array}{l}\text { The insurer believes in the insurances of } \\
\text { the Imams }\end{array}$ \\
\hline \multirow{2}{*}{$\begin{array}{l}\text { Economic } \\
\text { contexts }\end{array}$} & Economic instability in society \\
\hline & Insecure insecurity from your future job \\
\hline \multirow{3}{*}{$\begin{array}{l}\text { Social } \\
\text { contexts }\end{array}$} & Insurance and social justice \\
\hline & Insurance and social welfare \\
\hline & Public trust in the insurance industry \\
\hline \multirow{4}{*}{$\begin{array}{l}\text { Quality of } \\
\text { other } \\
\text { insurance } \\
\text { companies } \\
\text { (quality of } \\
\text { other } \\
\text { competitors( }\end{array}$} & $\begin{array}{c}\text { Choose an insurer based on providing } \\
\text { accurate insurance services }\end{array}$ \\
\hline & $\begin{array}{c}\text { Choose an insurer based on providing } \\
\text { accurate insurance services }\end{array}$ \\
\hline & $\begin{array}{c}\text { Choice of the insurer based on the speed } \\
\text { of accountability and the processing of } \\
\text { demand }\end{array}$ \\
\hline & $\begin{array}{l}\text { Choice of the insurer based on the } \\
\text { apparent quality of the branches }\end{array}$ \\
\hline
\end{tabular}




\begin{tabular}{|c|c|}
\hline \multirow{2}{*}{$\begin{array}{c}\text { Mechanism } \\
\text { responds to } \\
\text { the obvious } \\
\text { and hidden } \\
\text { needs of } \\
\text { insurers }\end{array}$} & $\begin{array}{c}\text { Identify the needs and wants of insurers } \\
\text { Tangible actions to meet the insurer's } \\
\text { demands and needs }\end{array}$ \\
\cline { 2 - 2 } & $\begin{array}{c}\text { Appreciate the insurers regarding the } \\
\text { solity of services and improvement }\end{array}$ \\
& companions \\
\hline
\end{tabular}

\subsection{Selected coding}

At this stage, which is the last step in the triple encoders of the data theory methodology, the categories identified in the previous step should be embedded in the paradigm model.

Subsequently, each dimension of the paradigm model is discussed and related categories are introduced:

1. Main category (axis) is an idea, an incident or an event in which the concepts and categories are created on the axis. In this research, and according to the goals and categories identified, the category of "explicit and hidden needs of insurers" was considered as the main and main category. That is, the core of the conceptual model of research is the obvious and hidden needs of the insurer, which is influenced by a number of underlying and causal factors.

2. Casual circumstances: the set of conditions that cause the appearance of the phenomenon. Categories related to this dimension are defined as follows:

- "Inbound Needs": This category refers to the insider's innate desires, including mental and financial security, and having a backing.

- Islamic Worldview: This category refers to the Islamic worldview of the insurer and the insurer. That they believe that the will of God is on all matters and God is in charge of all matters.

- "Islamic Sharia Laws": This category refers to rulings that have been mentioned in the teachings of the Islamic religion regarding the desires or misconceptions of the transaction (such as honesty in the transaction, the absence of distinction between customers, the possibility of termination of the contract, etc.). 
- Religious beliefs: This category refers to some of the beliefs of insurers who are rooted in religion and religion (such as: repatriation of alms, insurances from the Imams, from any debt of the same)

3. Contexts: it shows the special circumstances in which the phenomenon (main category) is located. The context also includes the characteristics of the original category. In the present research, the categories related to this dimension were determined as follows:

- "Cultural-religious contexts": This category refers to a number of requirements and cultures derived from the religion of Islam, and include concepts such as: the need for prospective believers, the insurer's belief in the magnitude of divine, the believer is not biting from a hole twice.

- "Social contexts": This category refers to the general public view of insurance and includes concepts such as public trust in the insurance industry, the role of insurance in achieving social justice, and the role of insurance in achieving social welfare.

- "Economic Situation": This category refers to the economic situation of the community in which the insurer lives, and includes concepts such as: economic instability in the community and insecurity of the insurer's job.

4 Environmental conditions: Wide structural field and external factors that can affect the main category.

In the current research, the category "Other quality insurance companies (competitors' quality)" was determined as the category of environmental conditions. This category refers to concepts that play a role in choosing a particular insurance company by the insurer (such as: the speed of service delivery, the accuracy of service delivery, the physical characteristics of the place of delivery, etc.)

5. Strategies: A specific set of strategies or actions can be implemented in a context and under the specified mediation conditions, in order to realize the main category. In fact, strategies are actions that can turn the main issue into consequences. In this research, and according to the objectives and identified categories, the "mechanism of response to the obvious and hidden needs of insurers" was considered as a strategic category. This category refers to mechanisms and measures that are used to identify and respond to the apparent and hidden needs of insurers. In this regard, concepts such as identifying insurer's demands, carrying out tangible actions to meet 
the needs of the insurer, an insider's view of the quality of services and improvement strategies, and the modeling of successful insurance companies.

6. Consequences: The consequences of the realization of the pivotal category in the context of the causal, environmental and context conditions, and through specific strategies.

In this research, and according to the goals and categories identified, the category "obtaining internal satisfaction of insurance and establishing loyalty in him" was considered as a consequential category. In this category, concepts such as the level of satisfaction of the needs and requirements of the insurer, the insurer's intention is to purchase insurance services in the future, and to act as an agent for others by the insurer.

According to this description, the model presented in the form of figure (1) can be presented as a conceptual model of satisfaction of customers (insurers) of the insurance industry of Iran: 


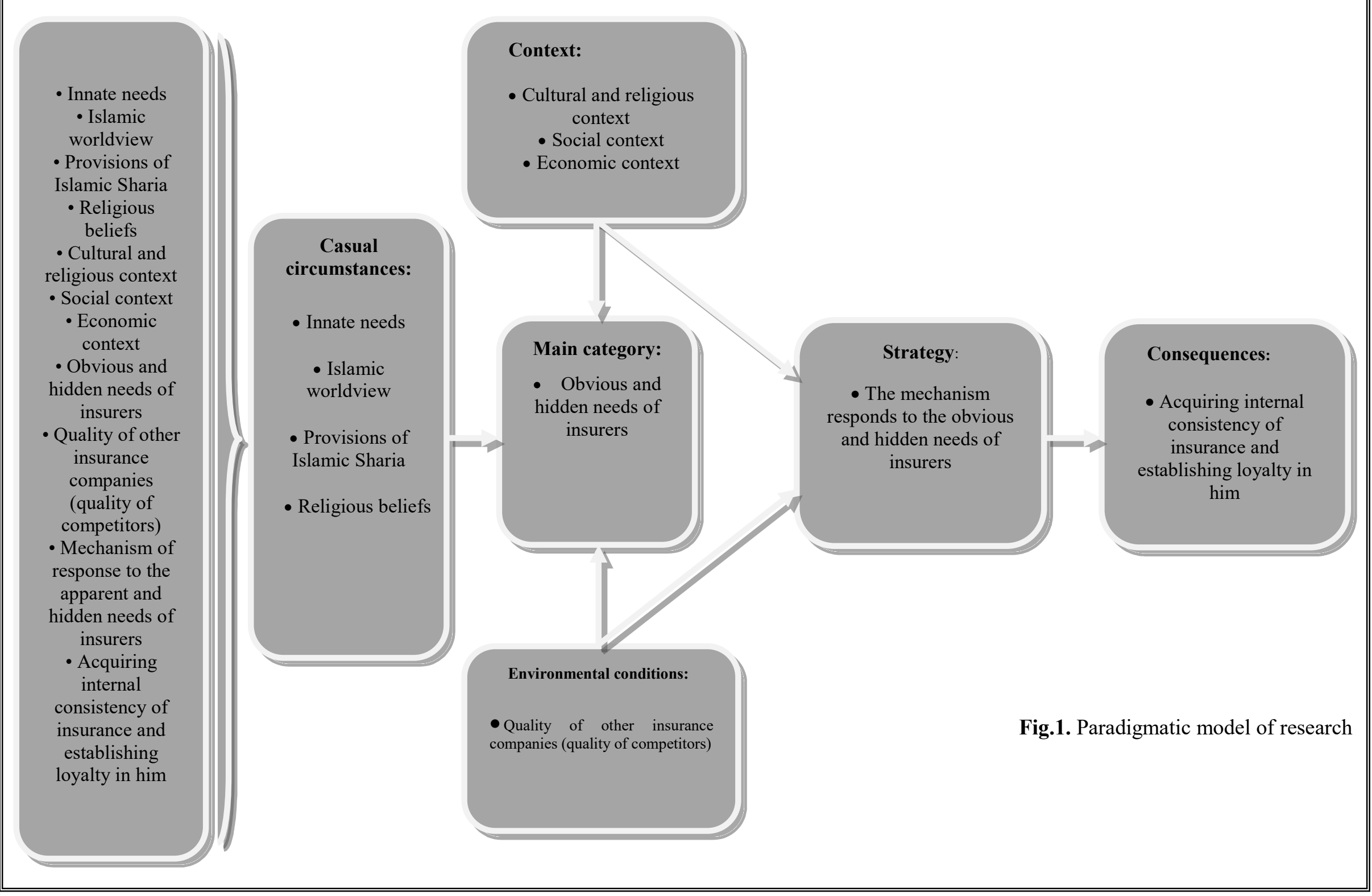




\subsection{The final conceptual model and the production of research hypotheses}

After conceptual modeling of the research, it was necessary to use the quantitative methods to fit this conceptual model into the real environment of the insurance industry. Therefore, the following conceptual model (Figure 2) and the fourteen hypotheses will be the basis of the research, and the research will follow the test of these hypotheses and the general fit of the model:

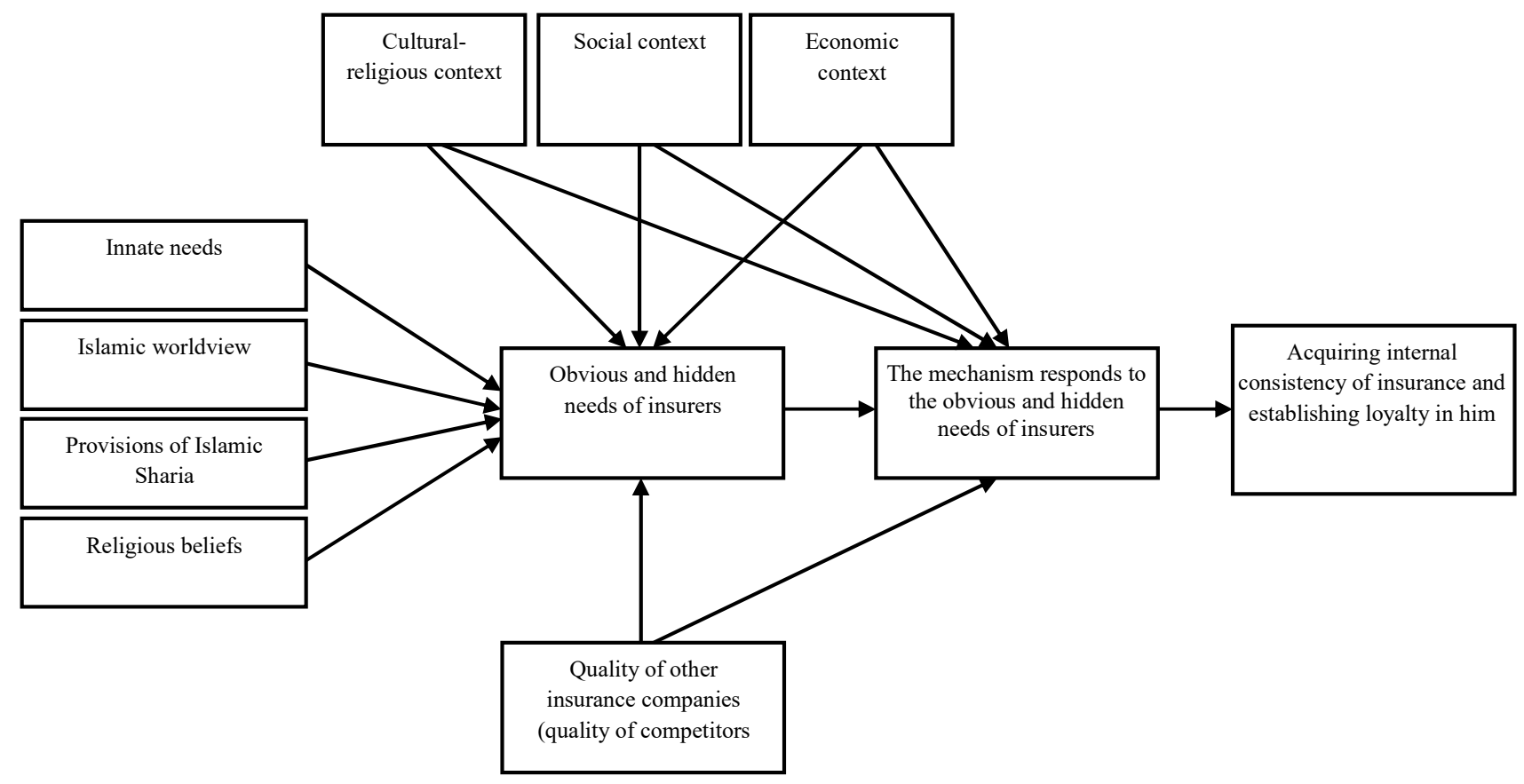

Fig.2. Conceptual model of research

\section{Hypotheses:}

- The "innate needs" have a significant effect on "obvious and hidden needs of the insurer."

- The "Islamic worldview" has a significant effect on the "obvious and hidden needs of the insurer".

- Provisions of Islamic Sharia have a significant effect on the "obvious and hidden needs of the insurer".

- "Religious beliefs" have a significant effect on the "obvious and hidden needs of the insurer".

- The "cultural-religious context" has a significant effect on the "obvious and hidden needs of the insurer." 
- The "social context" has a significant effect on the "obvious and hidden needs of the insurer".

- The "economic context" has a significant effect on the "obvious and hidden needs of the insurer".

- "The quality of other insurance companies (other competitors' quality)" has a significant effect on the "obvious and hidden needs of the insurer."

- The "cultural-religious context" has a significant effect on "the mechanism for responding to the apparent and hidden needs of insurers."

- The "social context" has a significant effect on "the mechanism for responding to the obvious and hidden needs of insurers."

- The "economic context" has a significant effect on "the mechanism for responding to the obvious and hidden needs of insurers."

- "The quality of other insurance companies (the quality of other competitors)" has a significant effect on "the mechanism for responding to the obvious and hidden needs of the insurer."

- The "obvious and hidden needs of the insurer" has a significant effect on "the mechanism for responding to the obvious and hidden needs of the insurer."

- "The mechanism for responding to the obvious and hidden needs of insurers" has a significant effect on "Acquiring internal consistency of insurance and establishing loyalty in him".

\section{DISCUSSION AND CONCLUSION}

This research eventually achieved an 11-variable model in the area of satisfaction of insurers in Iran's insurance industry after applying the qualitative approach. In this model, four variables, "physical needs", "Islamic worldview", "provisions of Islamic Sharia", and "religious beliefs" were identified as the primary causative factors. This part of the model is considered as one of the innovations of present research and the distinction of the model with other general models in the field of customer satisfaction. Also, four variables such as "economic contexts", "social contexts", "cultural-religious contexts", and "other quality insurance companies" were also identified as underlying and environmental factors. Of these, the first two variables (economic and social contexts), which were among the underlying variables, almost none of the previous models were found in customer satisfaction and they can be noticed as another distinguishing feature of this model compared to the models before 
them. In general, comparing the model of the present research with previous models, we can find the following table:

Table 3. Compare the model of the research with previous models

\begin{tabular}{|c|c|c|c|c|c|c|c|c|c|c|c|c|c|c|}
\hline Model & 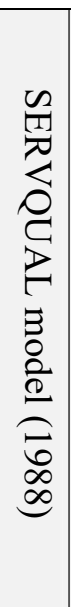 & 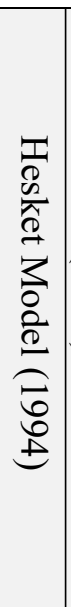 & (્) & 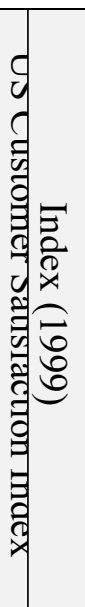 & 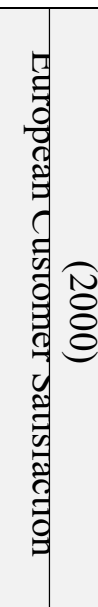 & 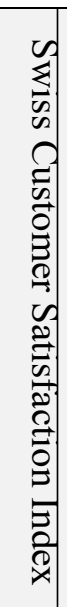 & 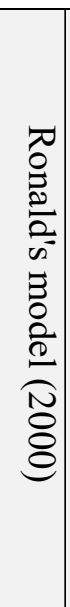 & 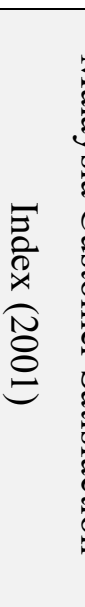 & 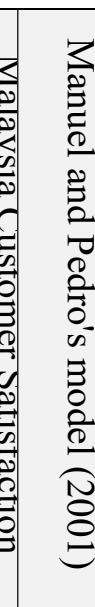 & 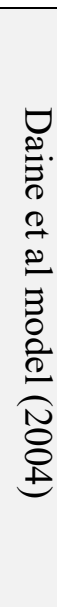 & 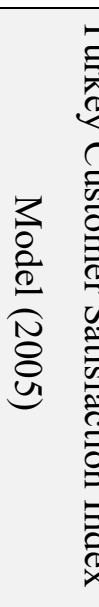 & $\mid$ & 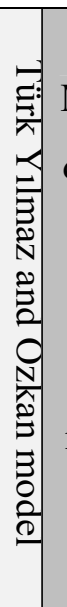 & $\begin{array}{l}\text { Model } \\
\text { derive } \\
\mathrm{d} \\
\text { from } \\
\text { this } \\
\text { resear } \\
\text { ch }\end{array}$ \\
\hline Expectations & & & $*$ & $*$ & & & & $*$ & $*$ & $*$ & $*$ & $*$ & & $*$ \\
\hline $\begin{array}{c}\text { Perceived } \\
\text { quality }\end{array}$ & & & $*$ & * & & & & $*$ & $*$ & $*$ & $*$ & $*$ & & $*$ \\
\hline $\begin{array}{c}\text { Perceived } \\
\text { value }\end{array}$ & & $*$ & $*$ & $*$ & & & $*$ & $*$ & $*$ & $*$ & $*$ & $*$ & & $*$ \\
\hline $\begin{array}{l}\text { Customer } \\
\text { satisfaction }\end{array}$ & & $*$ & $*$ & * & & k & $*$ & $*$ & $*$ & $*$ & $*$ & $*$ & & $*$ \\
\hline $\begin{array}{l}\text { Customer } \\
\text { complaint }\end{array}$ & & & $*$ & & & & & & & $*$ & & & & $*$ \\
\hline Image & & & & * & & & & $*$ & $*$ & $*$ & $*$ & $*$ & & $*$ \\
\hline $\begin{array}{c}\text { Client } \\
\text { conversation }\end{array}$ & & & & & & k & & & & & & & & \\
\hline $\begin{array}{c}\text { Employee } \\
\text { perceived } \\
\text { commitment }\end{array}$ & & & & & & & & & $*$ & & & & & $*$ \\
\hline $\begin{array}{c}\text { Perceived staff } \\
\text { satisfaction }\end{array}$ & & $*$ & & & & & $*$ & & $*$ & & & & & \\
\hline $\begin{array}{l}\text { Employee } \\
\text { perceived } \\
\text { loyalty }\end{array}$ & & $*$ & & & & & $*$ & & $*$ & & & & & \\
\hline
\end{tabular}




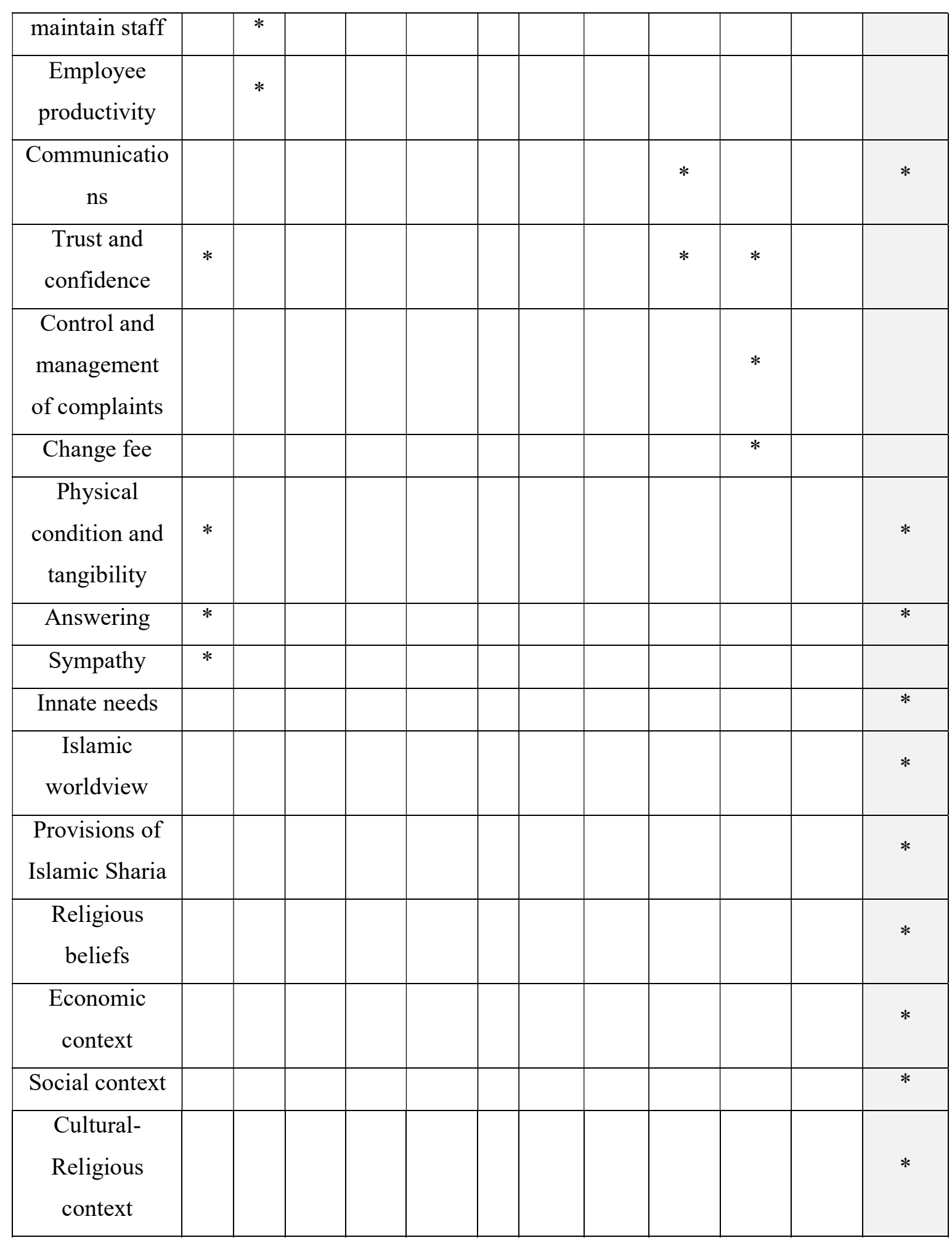

As it is seen, the model derived from this study, in addition to covering most of the variables and indicators in previous models, seven unique variables are included, and this distinction 
between the model's native and Iranian-Islamic dimension of the insurance industry helps the country.

Accordingly, it can be said that the present research theoretically has the following positive consequences:

- Entering the variable of the insurer's innate needs into the customer satisfaction model in the insurance industry.

- Entering the variable of insurers' Islamic worldview into the customer satisfaction model in the country's insurance industry.

- Entering the variables of provisions of Islamic Sharia into the model of customer satisfaction in the country's insurance industry.

- Entering the variables of the religious beliefs of insurers into the customer satisfaction model in the country's insurance industry.

- Entering the variables of the insurers' economic context into the customer satisfaction model in the country's insurance industry.

- Entering the variables of social insurers' context into the customer satisfaction model in the country's insurance industry.

- Entering variables of the cultural-religious context of insurers to the customer satisfaction model in the country's insurance industry.

- Entering a native model of insurers' satisfaction based on Iranian-Islamic characteristics specific to the country's insurance industry.

Also, it can be said that the present research is practical; it has the following positive consequences:

- Providing a comprehensive and applied model to the country's insurance industry regarding the process of creating satisfaction with insurers.

- Highlight some hidden dimensions in the process of creating satisfaction with insurers, which can be very helpful in developing strategies for insurers in the country.

\section{REFERENCES}

Chen-Ying Lee., Chih-Hsuan Tsao., Wan-Chuan Chang. (2015). The relationship between attitude toward using and customer satisfaction with mobile application services: An empirical study from the life insurance industry, Journal of Enterprise Information Management, Vol. 28, Issue: 5, pp.680-697.

Danaher P., Gallagher Rodger W, (1997), "Modeling Customer Satisfaction in Telecom New Zealand", European Journal of Marketing, Vol.31, No.2. 
Estiri, Mehrdad., Hosseini, Farshid., Yazdani, Hamidreza. (2011). Determinants of customer satisfaction in Islamic banking: evidence from Iran, International Journal of Islamic and Middle Eastern Finance and Management Vol. 4 No. 4, pp. 295-307.

Ganguli, Shirshendu., Roy, Sanjit Kumar. (2011). Generic technology-based service quality dimensions in banking Impact on customer satisfaction and loyalty, International Journal of Bank Marketing Vol. 29 No. 2, pp. 168-189.

Lee, Bruce C.Y. (2012). The determinants of consumer attitude toward service innovation the evidence of ETC system in Taiwan. Journal of Services Marketing, Vol.26 No.1, pp. 9-19.

Singh, Jaspal., Kaur, Gagandeep. (2011). Customer satisfaction and universal banks: an empirical study, International Journal of Commerce and Management Vol. 21 No. 4, pp. 327-348.

Tsu-Wei Yu., Lu-Ming Tseng. (2016). The role of salespeople in developing life insurance customer loyalty, International Journal of Retail \& Distribution Management, Vol. 44 Issue: 1, pp.22-37.

Upadhyaya, Deepika., Badlani, Manish. (2011). Service Quality Perception and Customer Satisfaction in Life Insurance Companies in India, International Conference on Technology and Business Management March 28-30 .

Wang, Chung-Yu., Wu, Li-Wei. (2012). Customer loyalty and the role of relationship length. Managing Service Quality, Vol. 22 No. 1, pp. 58-74.

\section{How to cite this article:}

Hosseini M H, Dehkordi L F, Parhizgar M M, Moezzi H. Designing the customer (insurers) satisfaction model of the iranian insurance industry emphasizing iranian-islamic characteristics. J. Fundam. Appl. Sci., 2017, 9(2S), 1255-1272. 